\title{
Diversity and abundance of the benthic macrofauna in lotic environments from the central region of Rio Grande do Sul State, Brazil
}

\author{
Luciane Ayres-Peres, Carolina C. Sokolowicz, Sandro Santos ${ }^{1}$ \\ Biota Neotropica v6 (n3) -http://www.biotaneotropica.org.br/v6n3/pt/abstract?article+bn02106032006 \\ Date Received 03/15/2006 \\ Revised 09/10/2006 \\ Accepted 10/02/2006 \\ (SS) Laboratório de Carcinologia \\ Departamento de Biologia, Centro de Ciências Naturais e Exatas \\ Universidade Federal de Santa Maria (UFSM) \\ 97105-900 - Santa Maria, RS - Brasil \\ ${ }^{1}$ Ssantos@smail.ufsm.br
}

\begin{abstract}
Ayres-Peres, L., Sokolowicz, C.C. and Santos, S. Diversity and abundance of the benthic macrofauna in lotic environments from the central region of Rio Grande do Sul State, Brazil. Biota Neotrop. Sep/Dec 2006 vol. 6, no. 3 http:// www.biotaneotropica.org.br/v6n3/pt/abstract?article+bn02106032006 ISSN 1676-0603.
\end{abstract}

The benthic fauna plays an important role in the trophic web and the nutrient flow of limnetic environments. This work aimed to study the diversity and abundance of the benthic invertebrates in four watercourses in the central region of the state of Rio Grande do Sul, Brazil. Sampling was done seasonally at each site, with a long-handled net at the margins (banks) and streambed, from November 2001 through September 2002. Margalef richness, Shannon diversity and Pielou evenness indices were applied to the data analysis. A total of 58 families and three other major taxa (Hirudinea, Oligochaeta and Copepoda) of invertebrates were identified. The highest values of diversity and abundance were recorded at the margins of the rivers, in the same pattern found in other tropical and subtropical regions. This is the first inventory of benthic invertebrates from central region of Rio Grande do Sul, which will be important for future studies of the diversity and conservation of this fauna, because human alterations of the environment have already begun.

Key words: benthic macroinvertebrates, richness index, evenness.

\section{Resumo}

Ayres-Peres, L., Sokolowicz, C.C. e Santos, S. Diversidade e abundância da macrofauna bentônica em ambientes lóticos da região central do Estado do Rio Grande do Sul, Brasil. Biota Neotrop. Sep/Dec 2006 vol. 6, no. 3 http:// www.biotaneotropica.org.br/v6n3/pt/abstract?article+bn02106032006.ISSN 1676-0603.

A fauna bentônica tem um importante papel nos ambientes límnicos, fazendo parte da cadeia trófica e participando do fluxo de nutrientes. O objetivo deste trabalho foi estudar a diversidade e a abundância dos invertebrados bentônicos em quatro cursos de água da região central do Estado do Rio Grande do Sul, Brasil. Amostragens foram realizadas sazonalmente com uma rede de mão (puçá) nas margens e nos leitos dos arroios em cada local de coleta, entre Novembro de 2001 e Setembro de 2002. Para analisar os dados foram aplicados os índices de riqueza de Margalef, diversidade de Shannon e uniformidade de Pielou. Um total de 58 famílias e três outros grandes taxa (Hirudinea, Oligochaeta e Copepoda) de invertebrados foram identificados. Os maiores valores de diversidade e abundância foram encontrados nas margens dos arroios, seguindo um padrão verificado para regiões tropicais e subtropicais. Este é o primeiro inventário de invertebrados bentônicos da região central do Estado Rio Grande do Sul, e servirá de base para futuros estudos sobre a diversidade e a conservação dessa fauna frente às alterações antrópicas no ambiente.

Palavras-chave: macroinvertebrados bentônicos, índice de riqueza, uniformidade.

http://www.biotaneotropica.org.br 


\section{Introduction}

Biological diversity means the variability among living organisms from all sources including, inter alia, terrestrial, marine and other aquatic ecosystems, and the ecological complexes of which they are part. This includes diversity within species, between species, and of ecosystems (Anonymous 2000).

Environmental complexity and high organism diversity are common features of tropical and subtropical ecosystems, both terrestrial and aquatic. Composed of several taxonomic groups associated with diversified substrata, the zoobenthos is one of the least known and studied of aquatic communities (Takeda et al. 1997).

Faunistic inventories are fundamental activities in studies on biodiversity. Nevertheless, few studies have inventoried the aquatic invertebrates of inland watercourses in southern Brazil. In the state of Rio Grande do Sul (RS), two such studies have been done, one in the Sinos River Basin (Stenert et al. 2002) and the other in Taquara and Tainhas brooks, in the municipal districts of Taquara and São Francisco de Paula, respectively (Bueno et al. 2003), both in the northeastern part of the state. It is important to cite the pioneering work developed by Kleerekoper (1990), which was the study of lotic environments of the littoral region of the Rio Grande do Sul.

Several studies of the diversity of the communities of benthic invertebrates of lotic environments, as well as their relationships with abiotic factors, have been carried out in Brazil. The main studies are those realized in the state of São Paulo by Uieda \& Gajardo (1996), Kikuchi \& Uieda (1998), and by Ribeiro \& Uieda (2005); in the state of Rio de Janeiro, by Baptista et al. (1998, 2001), and by Silveira et al. (2006); in Minas Gerais, by Galdean et al. (2001); in the state of Mato Grosso, the study by Serrano et al. (1998); and in Goiás, those by Oliveira et al. (1997) and Bispo \& Oliveira (1998).

In the international context, one can mention the studies developed in New Zealand by Quinn \& Hickey (1990); in Uruguay by Chalar (1994); in France by Bournaud et al. (1996) and Beisel et al. (1998); in Ecuador by Jacobsen et al. (1997); in Argentina by Fernández et al. (2001) and Miserendino (2001), and in Norway by Brittain et al. (2001), among others.

The central region of Rio Grande do Sul State (the Fourth Colony of Italian immigration) contains a remnant of the Atlantic Forest. UNESCO (United Nations Educational, Scientific and Cultural Organization) considers it a Pilot Site of the Biosphere Reserve (Itaqui 2002). Despite the recognized potential of this region, its zoobenthic communities have never been studied in detail. The present study aimed to analyze the diversity and abundance of benthic macroinvertebrates in the Fourth Colony region, in the municipal districts of Faxinal do Soturno, Ivorá, Nova Palma and Santa Maria (Arroio do Só locality).

\section{Materials and Methods}

1 Description of study sites. The sampling sites in central Rio Grande do Sul are characterized in Table 1. The substratum characteristics described in the table refer both to the margins (banks) and the streambed, because there were no substantial differences between these two regions of the rivers. The vegetation characteristics refer only to the margins.

This region (Figure 1) is situated in the transition zone between the Brazilian Meridional Plateau and the Central Depression of Rio Grande do Sul. It consists of flat alluvial plains, low flatlands alongside watercourses, and prairies with varying elevations. According to Pereira et al. (1989), four topographies can be distinguished in this region: Plateau Top (A), Plateau Edge (B), Prairies of the Peripheral Depression (C) and Alluvial Plains of the Peripheral Depression (D).

2 Sampling. Littoral and deep benthos samples were taken with a long-handled net $(0.2 \mathrm{~mm}$ mesh size), with a sampling area of $1,200 \mathrm{~cm}^{2}(40$ X $30 \mathrm{~cm})$ and $50 \mathrm{~cm}$ length (depth). At each locality, sampling was carried out for ten minutes at the margins (banks) and ten minutes in the beds of the watercourses, in a five meter stretch. The net was positioned upright on the streambed and the substrate upstream of the net was disturbed, which pushed the animals together with detritus into the mesh. Along the banks, the net was also introduced under the hanging vegetation, which was shaken to capture the macroinvertebrates (Kikuchi \& Uieda 1998).

The samples were collected once in each season of the year, at each sampling site, from November 2001 (spring) through September 2002 (winter).

The specimens were stained with Rose Bengal (CI-45 440 ) and fixed in $70 \%$ ethanol. In the laboratory, the animals were screened and identified according to appropriate literature sources (Chu 1949; Needham \& Needham 1962; Macan 1975; Bond-Buckup \& Buckup 1994; Lopreto \& Tell 1995). Identifications were taken to family level whenever possible, because there is a lack of specialized literature for identification of these animals. All specimens were deposited in the Scientific Collection of the Zoology Sector, UFSM (Universidade Federal de Santa Maria) (lots M-BIO: 75-227; 235-252; 269-283; 360-457; 534-563; 574-651; 671-692 and 709-740).

The richness and diversity of families in the four topographies in central Rio Grande do Sul were determined by computing the index of species richness (or families) (d) (Margalef 1958), Shannon Diversity index $(H)$ (Shannon \& Weaver 1949), and evenness index (e) (Pielou 1966). A $t$ test (Statistica 5.1) was applied to compare the index values found. The values of diversity, richness and equitability were compared between margins and streambeds, considering all sampling locations and each site separately. 
Table 1. Characterization of the sampling sites in the central region of Rio Grande do Sul State, Brazil. The substrate characteristics refer to the margins (banks) and bed of the rivers; vegetation characteristics refer only to the riverbanks. The samples were collected from November 2001 through September 2002. The values refer to the means of the seasonal samples (mean \pm standard deviation).

\begin{tabular}{|c|c|c|c|c|}
\hline & $\begin{array}{c}\text { Nova Palma } \\
\text { (A) }\end{array}$ & $\begin{array}{l}\text { Ivorá } \\
\text { (B) }\end{array}$ & $\begin{array}{c}\text { Faxinal do Soturno } \\
\text { (C) }\end{array}$ & $\begin{array}{c}\text { Santa Maria } \\
\text { (D) }\end{array}$ \\
\hline Site & Caimborá Stream & Melo Stream & Soturno River & $\begin{array}{c}\text { Vacacaí Mirim River } \\
\text { Tributary }\end{array}$ \\
\hline Location & $29^{\circ} 22^{\prime} 12^{\prime \prime} \mathrm{S} / 53^{\circ} 25^{\prime} 13^{\prime \prime} \mathrm{W}$ & $29^{\circ} 30^{\prime} 58^{\prime \prime} \mathrm{S} / 53^{\circ} 33^{\prime} 65^{\prime \prime} \mathrm{W}$ & $29^{\circ} 33^{\prime} 93^{\prime \prime} \mathrm{S} / 53^{\circ} 27^{\prime} 76^{\prime \prime} \mathrm{W}$ & $29^{\circ} 45^{\prime} 20^{\prime \prime} \mathrm{S} / 53^{\circ} 32^{\prime} 02^{\prime \prime} \mathrm{W}$ \\
\hline Vegetation & $\begin{array}{c}\text { No riparian forest } \\
\text { present; presence of } \\
\text { grasses at the margins }\end{array}$ & $\begin{array}{c}\text { Remnant of riparian } \\
\text { forest }\end{array}$ & $\begin{array}{l}\text { Strongly modified by } \\
\text { human activity; farms } \\
\text { and roads in the } \\
\text { region }\end{array}$ & Small shrubs \\
\hline Substrate & $\begin{array}{l}\text { Large and small } \\
\text { stones }\end{array}$ & $\begin{array}{l}\text { Large and small } \\
\text { stones }\end{array}$ & Small stones & $\begin{array}{l}\text { Sandy, with few } \\
\text { rocks }\end{array}$ \\
\hline Altitude (m) & 230 & 128 & 57 & 69 \\
\hline Width (m) & $3.60 \pm 0.59$ & $6.44 \pm 0.40$ & $36.25 \pm 0.94$ & $2.53 \pm 1.44$ \\
\hline Depth $(\mathrm{cm})$ & $21.87 \pm 10.53$ & $21.94 \pm 9.00$ & $25.63 \pm 9.71$ & $47.5 \pm 27.22$ \\
\hline $\begin{array}{c}\text { Water } \\
\text { Temperature } \\
\left({ }^{\circ} \mathrm{C}\right)\end{array}$ & $17.43 \pm 3.66$ & $17.30 \pm 4.17$ & $20.93 \pm 4.43$ & $20.55 \pm 1.61$ \\
\hline $\mathrm{pH}$ & $6.82 \pm 0.31$ & $7.62 \pm 0.25$ & $7.28 \pm 0.28$ & $7.10 \pm 0.19$ \\
\hline $\begin{array}{l}\text { Drift Velocity } \\
\qquad(\mathrm{m} / \mathrm{s})\end{array}$ & $0.75 \pm 0.53$ & $0.55 \pm 0.29$ & $0.75 \pm 0.33$ & $0.57 \pm 0.20$ \\
\hline
\end{tabular}

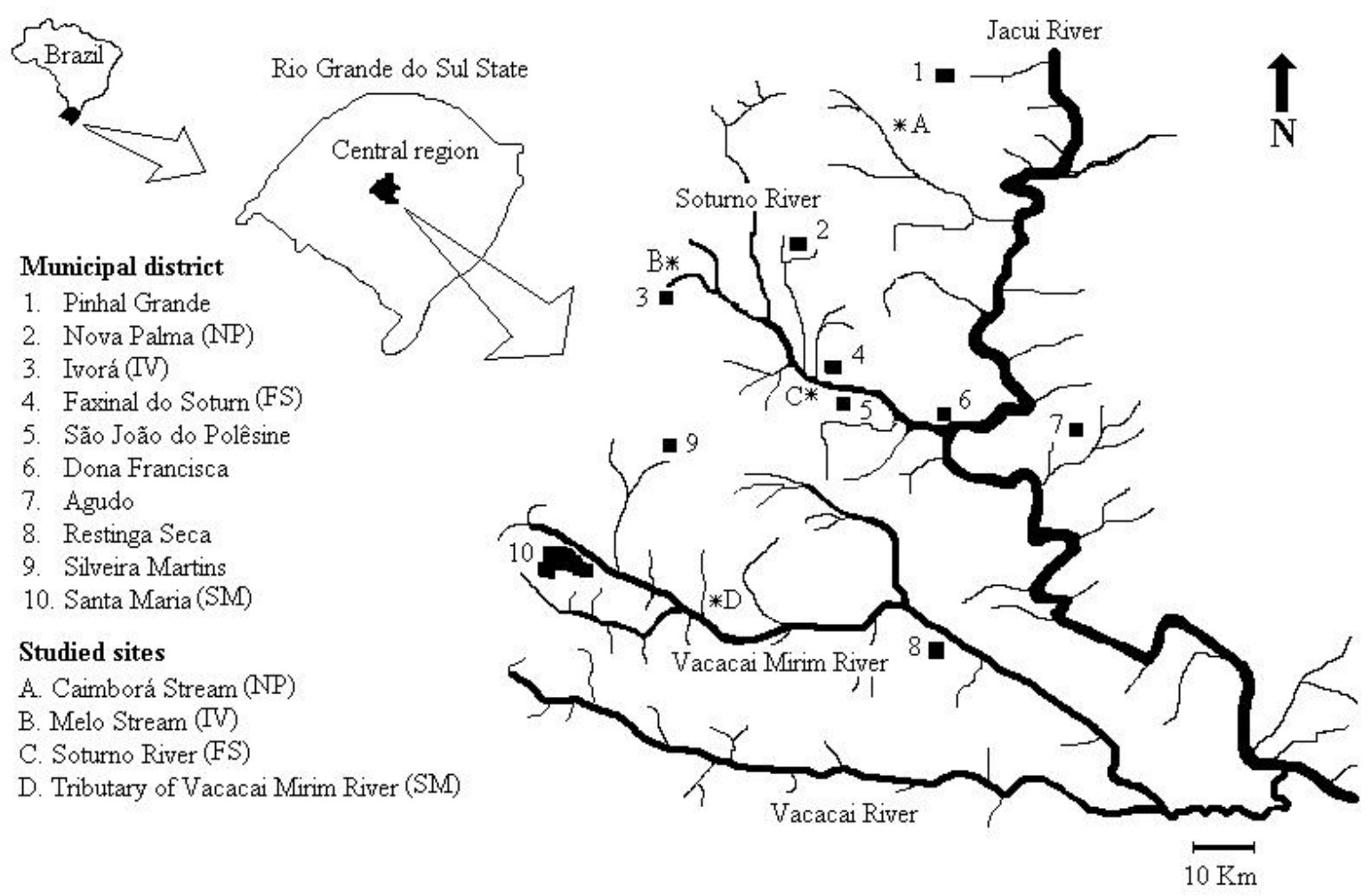

Figure 1. Central region of Rio Grande do Sul State, Brazil, with its cities (1 - 10) and the sampling locations (A - D). 


\section{Results}

A total of 58 families and three other taxa (classes) belonging to 20 orders and three phyla (Mollusca, Annelida, and Arthropoda) were identified at the study sites in the Fourth Colony. Class Insecta was predominant, with 11 orders and 42 families. A total of 32,287 specimens was collected (Table 2).

The data pertaining to the richness and diversity indices in the streambed or along the banks are summarized in Figure 2.

Nova Palma (Site A): In the course of four sampling episodes, 9,077 invertebrates were collected, belonging to 14 orders and 31 families (Table 2). Members of the families Aeglidae (Decapoda) and Acrididae (Orthoptera) were found only at Nova Palma. Along the streambanks, more than $90 \%$ of the invertebrates belonged to five families: Baetidae (37.3\%), Simuliidae (15.9\%), Gripopterygidae (14.7\%), Chironomidae (11.5\%) and Hydropsychidae (11.1\%). The same families were predominant in the streambed, but Simuliidae was the most abundant (37.4\%), followed by Gripopterygidae (18.0\%), Baetidae (17.7\%), Chironomidae (12.6\%) and Hydropsychidae (6.9\%) (Table 2).

Ivorá (Site B): In the Melo Stream, 7,397 animals were collected, belonging to 13 orders and 36 families (Table 2). The abundance of families was greater at the streambanks (33) than in the streambed (24). Members of three families were collected only at this site: Chrysomelidae, Curculionidae and Staphylinidae (Coleoptera). Four families comprised more than $90 \%$ of the fauna, both at the margin and in the streambed. The most abundant families along the banks were Chironomidae (55.4\%), Simuliidae (13.4\%), Baetidae (11.4\%) and Hydropsychidae (10.1\%); in the streambed, the most abundant families were Chironomidae (54.7\%), Baetidae (16.1\%), Simuliidae (11.0\%) and Hydropsychidae (10.3\%).

Faxinal do Soturno (Site C): The total faunal composition at this site was 8,246 animals, distributed in 17 orders and 38 families (Table 2). At the streambanks, 35 families occurred, and in the streambed, 25 families. The families Planorbidae (Basommatophora), Cymothoidae (Isopoda; fish parasites), Argulidae (Arguloida), Euthyplociidae (Ephemeroptera) and Gerridae (Hemiptera) were found only at this site. Along the streambanks, more than $80 \%$ of the animals belonged to five groups: Chironomidae (40.3\%), Baetidae (18.3\%), Oligochaeta (9.2\%), Leptophlebiidae (9.2\%) and Tricorythidae (6.1\%). In the streambed, the most abundant families were Leptophlebiidae (31.0\%), Elmidae (21.7\%), Chironomidae (13.2\%), Baetidae (9.9\%) and Tricorythidae (7.2\%).

Santa Maria (Site D): In Vacacai Mirim River Tributary, 7,567 animals were collected, in 20 orders and 42 families. Groups collected only at this site were: Hyriidae (Unionida); Salticidae and Tetragnathidae (Araneae); Copepoda; Trichodactylidae (Decapoda); Eumastacidae
(Orthoptera); Cicadellidae, Coccidae, and Delphacidae (Homoptera) and Noteridae (Coleoptera) (Table 2). Members of the family Chironomidae were extremely abundant at Santa Maria, representing more than $90 \%$ of the invertebrates in the streambed; along the streambanks, chironomids represented 57.7\%, followed by Simuliidae (10.6\%), Oligochaeta (8.1\%) and Hydropsychidae (6.2\%).

When all sites were compared to assess for any difference between the banks and streambeds, a significant difference was only found for the Margalef Index $(t=9.942$, $p<0.05$ ), where the banks of the rivers were significantly richer in number of taxa than were the streambeds. Relating each sampling site with its streambanks and streambed, significant differences were as follows: diversity (Shannon) was higher along the banks of the Arroio do Só than in its streambed ( $t=0.379, \mathrm{p}<0.05$ ), and richness (Margalef) was higher at the streambanks in Ivorá $(t=4.00, \mathrm{p}<0.05)$ and Arroio do Só $(t=10.54, \mathrm{p}<0.05)$. The values of equitability (Pielou) did not vary significantly between the bank areas and streambeds.

When the streambanks in the different locations (four sampling sites) were compared, no differences concerning diversity and equitability were found; however, the bank areas of Vacacai Mirim Tributary (Santa Maria) were richer in number of taxa than those of Caimborá Stream (Nova Palma) $(t=-3.91, \mathrm{p}<0.05)$.

For the streambeds of the sample sites, diversity $(t=$ 4.30, $\mathrm{p}<0.05)$ and richness $(t=0.401, \mathrm{p}<0.05)$ were both significantly higher in Faxinal do Soturno than in Santa Maria.

\section{Discussion}

Although statistical differences were not found (only for richness between the margins of Santa Maria and Nova Palma; also diversity and richness were significantly higher in Faxinal do Soturno than in Santa Maria) among the four analyzed relief units, the Prairie of the Peripheral Depression (Faxinal do Soturno municipal district) showed the greatest diversity.

According to Oliveira et al. (1997), biological diversity is the result of historical and ecological events, regional as well as local ones. Diversity is generally reduced by destabilization of the ecological system caused by human interference.

Although it showed the highest richness, Santa Maria was the least diverse. This site contained a larger number of individuals from a single family (Chironomidae), which was reflected in the lowest evenness index of all the sites. The higher richness at this site was confirmed by the richness index, using the abundance of the families.

The high richness found at site $\mathrm{D}$ reflects the diverse habitats in this region, which has vegetation along the banks above the watercourse, allowing the survival of several taxa adapted to live between the aquatic and terrestrial environments. Also, this site has a sandy substrate, whereas the other areas have rocky substrates. The vegetation hanging 
Table 2. Benthic macroinvertebrate abundance (\%) at each sampling site, collected from November 2001 through September 2002 (M = Margin; B = Bed; “-” = absent animals”. *For the data analysis, the labeled groups were considered as an Order and as a Family).

\begin{tabular}{|c|c|c|c|c|c|c|c|c|}
\hline & \multicolumn{2}{|c|}{ Nova Palma (A) } & \multicolumn{2}{|c|}{ Ivorá (B) } & \multicolumn{2}{|c|}{ F. do Soturno $(\mathrm{C})$} & \multicolumn{2}{|c|}{ Santa Maria (D) } \\
\hline & $\mathrm{M}$ & B & $\mathrm{M}$ & $\mathrm{B}$ & $\mathrm{M}$ & B & $\mathrm{M}$ & $\mathrm{B}$ \\
\hline \multicolumn{9}{|l|}{ Class Bivalvia } \\
\hline \multicolumn{9}{|l|}{ Unionida } \\
\hline Hyriidae & - & - & - & - & - & - & 0.02 & 0.03 \\
\hline \multicolumn{9}{|l|}{ Veneroida } \\
\hline Corbiculidae & - & - & - & - & 0.3 & 3.0 & - & 1.5 \\
\hline Mycetopodidae & - & - & - & - & - & 0.04 & - & 0.07 \\
\hline Sphaeriidae & - & - & - & - & 0.3 & - & 0.5 & - \\
\hline
\end{tabular}

\section{Class Gastropoda}

Mesogastropoda

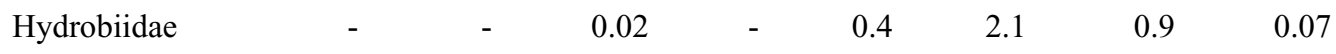

Basommatophora

Planorbidae

\section{Class Hirudinea*}

Class Oligochaeta*

$0.08 \quad 1.1$

$0.3 \quad 0.6$

$\begin{array}{lll}- & - & 0.02\end{array}$

\section{Class Arachnida}

Acari

Hydrachnellidae

$$
0.02
$$

0.07

0.04

1.4

0.4

0.03

Araneae

Araneidae
Clubionnidae
Pisauridae
Salticidae

Tetragnathidae

\section{Class Branchiopoda}

Arguloida

$$
\text { Argulidae }
$$

\section{Class Copepoda*}

\section{Class Malacostraca}

Decapoda

$$
\text { Aeglidae }
$$

Trichodactylidae

Isopoda

$$
\text { Cymothoidae }
$$

$$
0.02 \quad 0.04
$$




\begin{tabular}{ccccccccc}
\hline & \multicolumn{2}{c}{ Nova Palma (A) } & \multicolumn{2}{c}{ Ivorá (B) } & \multicolumn{2}{c}{ F. do Soturno (C) } & \multicolumn{2}{c}{ Santa Maria (D) } \\
\cline { 2 - 8 } & M & B & M & B & M & B & M & B \\
\hline
\end{tabular}

\section{Class Insecta}

Collembola

Entomobryidae

0.02

0.02

0.4

Coleoptera

Chrysomelidae

Curculionidae

Dryopidae

Dytiscidae

Elmidae

Heteroceridae

Hydrophilidae

Noteridae

Psephenidae

Staphylinidae

Diptera

Ceratopogonidae

Chironomidae

Dolichopodidae

Empididae

Simuliidae

Tipulidae

0

$-0.02$

Ephemeroptera

Baetidae
Caenidae

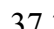

Caenidae

Euthyplociidae

Leptophlebiidae

Tricorythidae

$\begin{array}{cccccccc}- & 0.07 & 0.07 & - & 0.3 & 0.2 & 0.3 & 0.03 \\ 11.5 & 12.6 & 55.4 & 54.7 & 40.3 & 13.2 & 57.7 & 90.4 \\ 0.02 & - & - & 0.2 & 0.02 & - & - & - \\ - & - & 0.06 & 0.04 & - & - & 0.03 & - \\ 15.9 & 37.4 & 13.4 & 11.0 & 3.4 & 0.1 & 10.6 & 1.6 \\ 0.05 & - & 0.4 & 0.7 & 0.4 & 0.5 & 0.04 & 0.03\end{array}$

Hemiptera

Gerridae
Limnocoridae
Veliidae

Homoptera
Cicadellidae
Coccidae
Delphacidae

Megaloptera

$$
\text { Corydalidae }
$$

0.07

0.2

$0.5 \quad 0.06$

0.3

0.06

0.2

http://www.biotaneotropica.org.br 
Ayres-Peres, L., Sokolowicz, C.C. e Santos, S. - Biota Neotropica, v6 (n3) - bn02106032006

\begin{tabular}{|c|c|c|c|c|c|c|c|c|}
\hline & \multicolumn{2}{|c|}{ Nova Palma (A) } & \multicolumn{2}{|c|}{ Ivorá (B) } & \multicolumn{2}{|c|}{ F. do Soturno (C) } & \multicolumn{2}{|c|}{ Santa Maria (D) } \\
\hline & $\mathrm{M}$ & $\mathrm{B}$ & $\mathrm{M}$ & $\mathrm{B}$ & $\mathrm{M}$ & $\mathrm{B}$ & $\mathrm{M}$ & $\mathrm{B}$ \\
\hline \multicolumn{9}{|l|}{ Odonata } \\
\hline Calopterygidae & - & - & 0.06 & - & 0.02 & 0.04 & 0.5 & 0.03 \\
\hline Coenagrionidae & 0.2 & 0.3 & 0.02 & 0.09 & - & - & - & - \\
\hline Gomphidae & 0.03 & - & 0.06 & 0.06 & 0.02 & - & 0.1 & 0.03 \\
\hline Libellulidae & 0.03 & - & 0.2 & - & 0.05 & - & 0.02 & 0.03 \\
\hline \multicolumn{9}{|l|}{ Orthoptera } \\
\hline Acrididae & 0.02 & - & - & - & - & - & - & - \\
\hline Eumastacidae & - & - & - & - & - & - & 0.02 & - \\
\hline \multicolumn{9}{|l|}{ Plecoptera } \\
\hline Gripopterygidae & 14.7 & 18.0 & 2.0 & 0.7 & 1.8 & 0.1 & 0.2 & - \\
\hline Perlidae & 0.05 & 0.1 & 0.3 & 0.3 & 0.4 & 1.7 & - & - \\
\hline \multicolumn{9}{|l|}{ Trichoptera } \\
\hline Glossosomatidae & - & - & 1.6 & 2.2 & 0.2 & 0.4 & 0.1 & 0.06 \\
\hline Hydropsychidae & 11.1 & 6.9 & 10.1 & 10.3 & 1.6 & 4.2 & 6.2 & 1.7 \\
\hline Hydroptilidae & 0.03 & 0.1 & 0.02 & - & - & 0.04 & - & - \\
\hline Limnephilidae & - & - & - & - & 0.06 & - & 0.02 & 0.03 \\
\hline Philopotamidae & 0.03 & - & 0.5 & 0.3 & 0.1 & 1.2 & - & - \\
\hline Total & 100 & 100 & 100 & 100 & 100 & 100 & 100 & 100 \\
\hline
\end{tabular}




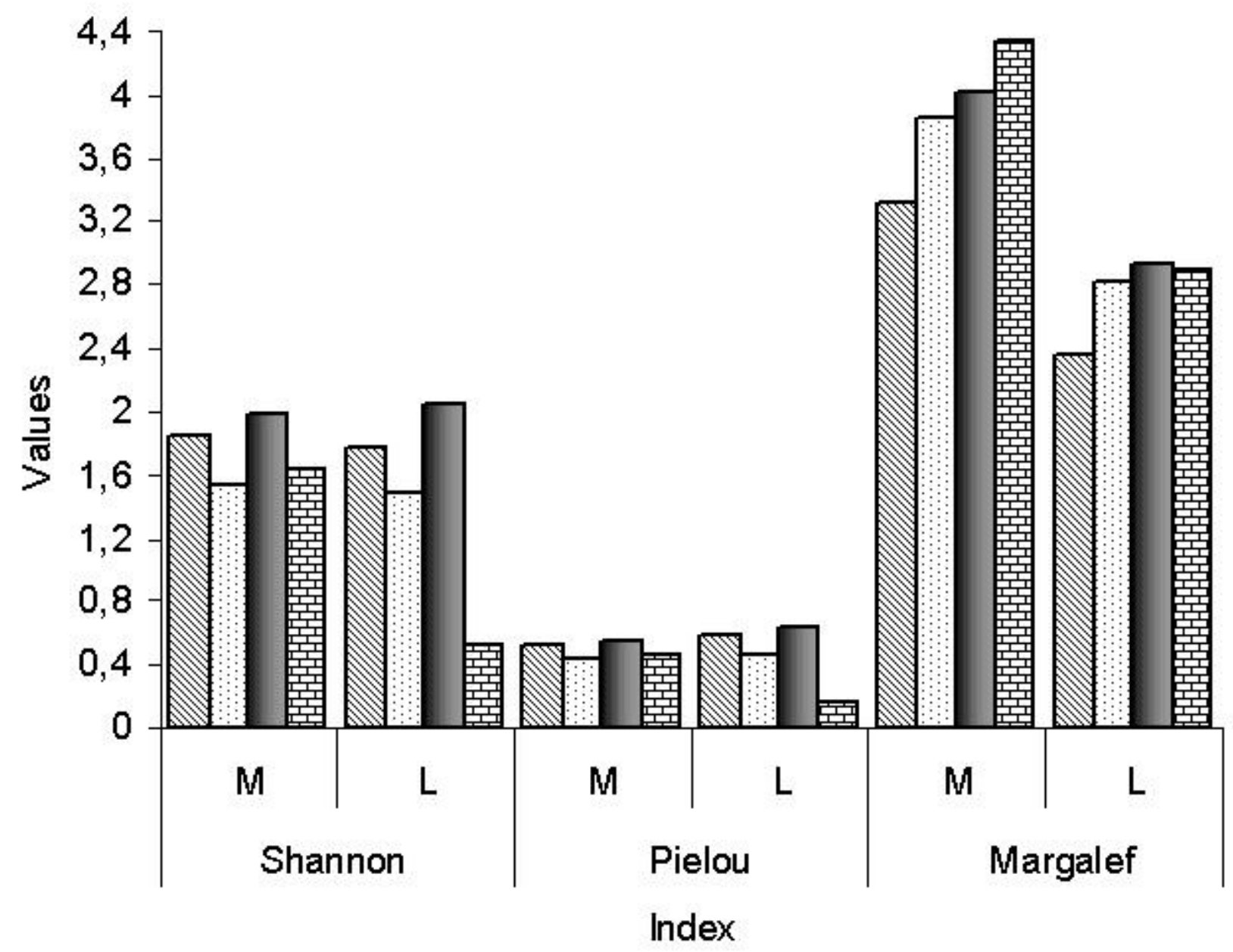

$\mathbb{N P} \square \mathrm{N} \square \mathrm{FS}$ 由 $\mathrm{SM}$

Figure 2. Diversity, evenness, and richness indices for the margins $(M)$ and the beds $(L)$ of the four watercourses sampled in the Fourth Colony. NP - Nova Palma; IV - Ivorá; FS - Faxinal do Soturno and SM - Santa Maria. Samples were taken from November 2001 through September 2002. 
over the water can be partly flooded during the rainy season, thus affording new locales for shelter and feeding (Kikuchi \& Uieda 1998).

The generally higher abundance of invertebrates along the banks than in the streambed has also been observed in other areas, such as the floodplain of the Paraná River (Takeda et al. 1997) and five lagoons in the state of Minas Gerais (Santos et al. 1998).

Spatial heterogeneity can explain the high diversity and abundance in littoral regions, provided that it confers on these areas several transitional habitats between the land and the water, which can be colonized by both terrestrial and aquatic animals (Takeda et al. 1997). Transitional habitats can supply a wide variety of resources for food as well as shelter for the aquatic macroinvertebrates. This area, with shrubby bank vegetation, provides an environment that can be often used by groups such as Hemiptera, Homoptera, Lepidoptera and Orthoptera. According to Vinson \& Hawkins (1998), high diversity is related to greater habitat heterogeneity and complexity, and species richness increased with habitat heterogeneity, total abundance increased with food availability, and both equitability and diversity seemed to increase with substrate stability (Beisel et al. 1998).

Some families were collected in only one locality, such as Aeglidae, found only at Nova Palma. Aegla is an endemic genus in South America (Bond-Buckup \& Buckup 1994) that prefers environments with moderate flow in which turbulence favors water oxygenation (Chalar 1994), such as at Nova Palma.

Ten families were found only at Santa Maria, the locality with the most exclusive families (Table 2). The presence of trichodactylid crabs, which are characteristic of stagnant waters and thin substrates, spiders, and some Homoptera, which live associated with shrubby vegetation along the banks, distinguished this site from the others.

Several families (such as Hyriidae, Mycetopodidae, Acrididae, Eumastacidae, Cicadellidae, Coccidae and Delpachidae) were found at a low frequency; hence it is not possible to state whether they are typical or casual groups in these areas.

According to Hynes (1970), insects are the most important group in analyzing diversity and abundance in running waters. The results for the Fourth Colony agree with this observation, because 42 families of insects were collected, representing $95 \%$ of the sampled communities. The same pattern, with a high abundance of Insecta, was also observed in other studies in southeastern and central-western Brazil, such as in Uieda \& Gajardo (1996), Kikuchi \& Uieda (1998), Serrano et al. (1998), Bueno et al. (2003) and Ribeiro \& Uieda (2005).

The taxa found in the central region of Rio Grande do Sul comprised a large part of the macrozoobenthos groups which are often cited in the literature as typical of lotic environments (Serrano et al. 1998; Kikuchi \& Uieda 1998; Galdean et al. 2001; Bueno et al. 2003; Ribeiro \& Uieda 2005), following the family-level fauna model observed in other regions of Brazil.

In relation to the diversity indices, the data for the four habitats studied were similar to those found in other areas. In the present study, estimated diversities varied from 1.48 at Ivorá to 2.06 at Faxinal do Soturno. Oliveira et al. (1997), evaluating the diversity of Ephemeroptera, Plecoptera and Trichoptera in an Ecological Park in the state of Goiás, found that diversity varied from 1.00 to 3.80, during the course of the year and at the different sampling points. Fernández et al. (2001), assessing diversity in six subtropical rivers in northeastern Argentina, also found similar values, with Shannon indices between 1.80 and 2.50. Bueno et al. (2003) obtained diversity values between 1.00 and 2.50 . According to Beisel et al. (1998), structurally complex habitats are expected to sustain more diverse communities than are structurally simple ones.

Comparing the present results for Insecta (the dominant group in continental aquatic ecosystems) with those of Bueno et al. (2003) in the northeast region of Rio Grande do Sul, the central region showed more orders and families than did the northeast region (11 orders and 42 families versus 10 orders and 40 families, respectively). Despite the occurrence of more families, certain families recorded for the northeast region were not found in the central region: Naucoridae and Hebridae (Hemiptera), Hypogastruridae (Collembola), Pyralidae (Lepidoptera) and Leptoceridae (Trichoptera). The family Chironomidae, representing almost $40 \%$ of the total insect families, was the most abundant in streambeds as well as along the banks, at nearly all the sites except Nova Palma and in the bed of the Soturno River. In the northeast region, chironomids were also dominant in most samples, with rates varying from $22.24 \%$ to $48.92 \%$ of the community (Bueno et al. 2003).

In Nova Palma the families Baetidae and Simuliidae were the most abundant. In the bed of the Soturno River, Leptophlebiidae, an indicator family of organically rich waters (Pérez 1988), predominated.

Chironomidae figured in more than $67 \%$ of the community in Vacacai Mirim Tributary (Santa Maria, site D), possibly because of the substratum characteristics, since a determinant factor for community structure is the type of streambed. This family is nearly always dominant in lotic as well as in lentic habitats, because of its tolerance for adverse situations, such as hypoxia, and its high competitive capacity (Marques et al. 1999; Callisto et al. 2001; Bueno et al. 2003; Ribeiro \& Uieda 2005).

Solid substrates favor those invertebrates which have morphological adaptations to attach or to move about to capture food and to escape from predators. On this type of 
bottom, mainly rocky substrates, the unevenness can facilitate locomotion and fixation of some invertebrates, by slowing the water current and providing different microhabitats. Soft bottoms favor those organisms adapted to the dominant texture (Takeda et al. 1997), as in Santa Maria. Bueno et al. (2003) also observed that the heterogeneity of rocky substrate, mainly at Tainhas, supported higher richness and mean diversity of species (for all seasons of the year except summer); whereas at Taquara, the other study point, the sandy substrate limited the distribution of certain families, because of the scarcity of refuges and food.

Of all the sites studied, the Soturno River, with its banks eroded because of the destruction of the gallery forest, is probably the most modified by human activity. However, the highest faunal diversity recorded in this study was found at this site. In agreement with Oliveira \& Froehlich (1997), this can probably be explained by the favoring of the formation of diverse microhabitats, some of them more exposed to the current, with a predominance of pebbles, others having slower currents, with sandy substrate and other sediments.

Brazil possesses a vast hydrographic network, and few surveys of the aquatic entomofauna have been done, mainly because of the difficulty of taxonomic identification of immature forms (Oliveira \& Froehlich 1997). In this context, the present study introduces new information about the invertebrate fauna of the lotic environments of central Rio Grande do Sul. Moreover, it provides a basis for future studies leading to monitoring and to better knowledge of the structure of aquatic communities in the state.

\section{Acknowledgements}

We are grateful to the biologists Daiana Msc. Castiglioni, Msc. Daniela Barcelos and João Vítor Trindade Bitencourt for the help with the samplings and screening of the materials; to Msc. Marcia R. Spies for the identification of mollusks and the help with the statistical analyses; to Msc. Leocádia Indrusiaki for the identification of spiders; and to CNPq for the concession of a Scientific Initiation Scholarship to L.A.P.

\section{Literature cited}

ANONYMOUS. 2000. Convenção sobre a diversidade biológica: Conferência para a adoção do texto acordado da CDB - ato final de Nairobi. Brasília: MMA/SBF, (Biodiversidade 2). 60 pp.

BAPTISTA, D.F., DORVILLÉ, L.F.M., BUSS, D.F., NESSIMIAN, J.L. \& SOARES, L.H.J. 1998. Distribuição de comunidades de insetos aquáticos no gradiente longitudinal de uma bacia fluvial do sudeste brasileiro. In Ecologia de insetos aquáticos (J.L. Nessimian \& A.L. Carvalho, eds). Oecol. Bras., UFRJ, Rio de Janeiro, $5^{\circ}$ vol.: 191-207.
BAPTISTA, D.F., BUSS, D.F., DORVILLÉ, L.F.M. \& NESSIMIAN, J.L. 2001. Diversity and habitat preference of aquatic insects along the longitudinal gradient of the Macaé River Basin, Rio de Janeiro, Brazil. Rev. Bras. Biol. 61(2): 249-258.

BEISEL, J-N, USSEGLIO-POLATERA, P., THOMAS, S. \& MORETEAU, J-C. 1998. Stream community structure in relation to spatial variation: the influence of mesohabitat characteristics. Hydrobiologia 389: 73-88.

BISPO, P.C. \& OLIVEIRA, L.G. 1998. Distribuição espacial de insetos aquáticos (Ephemeroptera, Plecoptera e Trichoptera) em córregos de cerrado do Parque Ecológico de Goiânia, Estado de Goiás. In Ecologia de insetos aquáticos (J.L. Nessimian \& A.L. Carvalho, eds). Oecol. Bras., UFRJ, Rio de Janeiro, $5^{\circ}$ vol.: 175-189.

BOND-BUCKUP, G \& BUCKUP, L. 1994. A família Aeglidae (Crustacea, Decapoda, Anomura). Arq. Zool. 32(4): 159-346.

BOURNAUD, M., CELLOT, B., RICHOUX, P.\&BERRAHOU, A. 1996. Macroinvertebrate community structure and environmental characteristics along a river: congruity of patterns for identification to species or family. J. N. Am. Benthol. Soc. 15(2): 232-253.

BRITTAIN, J.E., SALTVEIT, S.J., CASTELLA, E., BOGEN, J., BØNSNES, T.E., BLAKAR, I., BREMNES, T., HAUG, I. \& VELLE, G. 2001. The macroinvertebrate communities of two contrasting Norwegian glacial rivers in relation to environmental variables. Freshwater Biol. 46: 1723-1736.

BUENO, A.A.P., BOND-BUCKUP, G. \& FERREIRA, B.D.P. 2003. Estrutura da comunidade de invertebrados bentônicos em dois cursos d’água do Rio Grande do Sul, Brasil. Revta. Bras. Zool. 20(1): 115-125.

CALlistO, M., MORETTI, M. \& GOULART, M. 2001. Macroinvertebrados bentônicos como ferramenta para avaliar a saúde de riachos. Rev. Bras. Rec. Hídric. 6(1): 71-82.

CHALAR, G. 1994. Zoobenthic composition and abundance in the Arroyo Toledo (Uruguay), and its relation with the water quality. Rev. Chil. Hist. Nat. 67 (2): 129-141.

CHU, H.F. 1949. The immature insect. Dubuque: Wm.C Brown company publishers. $234 \mathrm{pp}$.

FERNÁNDEZ, H.R., ROMERO, F., PERALTA, M. \& GROSSO, L. 2001. La diversidad del zoobentos em ríos de montaña del noroeste de Argentina: comparación entre seis ríos. Ecol. Austral 11: 9-16.

GALDEAN, N., CALLISTO, M. \& BARBOSA, F.A.R. 2001. Biodiversity assessment of benthic macroinvertebrates in altitudinal lotic ecossysytems of Serra do Cipó (MG, Brazil). Rev. Bras. Biol. 61(2): 239-248.

HYNES, H.B.N. 1970. The ecology of running waters. $3^{\text {rd }}$ ed. Toronto press, Toronto. 555 pp.

ITAQUI, J. (ed). 2002. Quarta-Colônia: inventários técnicos. Condesus: Santa Maria. 256 pp. 
JACOBSEN, D., SCHULTZ, R. \& ENCALADA, A. 1997. Structure and diversity of stream invertebrate assemblages: the influence of temperature with altitude and latitude. Freshwater Biol. 38: 247-261.

KIKUCHI, R.M. \& UIEDA, V.S. 1998. Composição da comunidade de invertebrados de um ambiente lótico tropical e sua variação espacial e temporal. In Ecologia de insetos aquáticos (J.L. Nessimian \& A.L. Carvalho, eds.). Oecol. Bras., UFRJ, Rio de Janeiro, 5º vol.:157-173.

KLEEREKOPER, H. 1990. Introdução ao estudo da Limnologia. 2ed. Ed. da Universidade/UFRGS: Porto Alegre. 329p (Fac-similar de: Rio de Janeiro: Ministério da Agricultura, Serviço de Informação Agrícola, 1944).

LOPRETO, E.C. \& TELL, G. 1995. Ecosistemas de aguas continentales: metodologías para su estudio. vol. 1, 2 and 3. Ediciones Sur, La Plata. 1397 p

MACAN, T.T. 1975. Guía de animales invertebrados de agua dulce. Ediciones Universidad de Navarra SA, Pamplona. 118 pp.

MARGALEF, R. 1958. Information theory in ecology. General Systems 3: 36-71.

MARQUES, M.GS.M., FERREIRA, R.L. \& BARBOSA, F.A.R. 1999. A comunidade de macroinvertebrados aquáticos e características linmológicas das Lagoas Carioca e da Barra, Parque Estadual do Rio Doce, MG. Rev. Bras. Biol. 59(2): 203-210.

MISERENDINO, M.L. 2001. Macroinvertebrate assemblages in Andean Patagonian rivers and streams: environmental relationships. Hydrobiologia 444(1-3): 147-158.

NEEDHAM, J.G. \& NEEDHAM, K.W. 1962. A guide to study of fresh-water biology. Holden Day, San Francisco. 108 pp.

OLIVEIRA, L.G. \& FROEHLICH, C.G. 1997. Diversity and community structure of aquatic insects (Ephemeroptera, Plecoptera and Trichoptera) in a southeastern Brazilian mountain stream, Acta Limnol. Brasil. 9: 139-148.

OLIVEIRA, L.G., BISPO, P.C. \& SÁ, N.C.de. 1997. Ecologia de comunidades de insetos bentônicos (Ephemeroptera, Plecoptera e Trichoptera), em córregos do Parque Ecológico de Goiânia, Goiás, Brasil. Revta. Bras. Zool. 14(2): 867-876.

PEREIRA, P.R.B., GARCIA-NETTO, L.R., BORIN, C.J.A. \& SARTORI, M.G.B. 1989. Contribuição à geografia física de Santa Maria: unidades de paisagem. Geografia - Ensino e Pesquisa 3: 37- 68.

PÉREZ, G.R. 1988. Guía para el estudio de los macroinvertebrados acuáticos del departamento de Antioquia. fen Colombia, Colciencias. 217 pp.

PIELOU, E.C. 1966. The measurement of diversity in different types of biological collections. J. Theor. Biol. 13: 131-144.

QUINN, J.M. \& HICKEY, C.W. 1990. Characterization and classification of benthic invertebrate communities in 88 New Zealand rivers in relation to environmental factors. New Zeal. J. Mar. Fresh. 24: 387-409.
RIBEIRO, L.O. \& UIEDA, V.S. 2005. Estrutura da comunidade de macroinvertebrados bentônicos de um riacho de serra em Itatinga, São Paulo, Brasil. Revta. Bras. Zool. 22(3): 613-618.

SANTOS, M.B.L., ROCHA, L.A., MARQUES, M.M.G.S.M., BARBOSA \& F.A.R. 1998. Diversidade e abundância da fauna bentônica de cinco lagoas do karste do planalto de Lagoa Santa, Minas Gerais In Ecologia de insetos aquáticos (J.L. Nessimian \& A.L. Carvalho, eds.). Oecol. Bras., UFRJ, Rio de Janeiro, $5^{\circ}$ vol.::77 - 89.

SERRANO, M.A.S., SEVERI, W. \& TOLEDO, V.J.S. 1998. Comunidades de Chironomidae e outros macroinvertebrados em um rio tropical de planície - Rio Bento Gomes/MT. In Ecologia de insetos aquáticos (J.L. Nessimian \& A.L. Carvalho, eds.). Oecol. Bras., UFRJ, Rio de Janeiro, $5^{\circ}$ vol.: 265-278.

SHANNON, C.E. \& WEAVER, W. 1949. The mathematical theory of communication. Urbana: University of Illinois Press. 117pp.

SILVEIRA, M.P., BUSS, D.F., NESSIMIAN, J.L. \& BAPTISTA, D.F. 2006. Spatial and temporal distribution of benthic macroinvertebrates in a southeastern Brazilian river. Braz. J. Biol. 66(2B): 623-632.

STENERT, C., SANTOS, E.M., OLIVA, T.D. \& MALTCHIK, L. 2002. Diversidade de macroinvertebrados em áreas úmidas na Bacia do Rio dos Sinos, RS, Brasil. Acta Biol. Leopold. 24 (2): 157-172.

TAKEDA, A.M., SHIMIZU, GY. \& HIGUTI, J. 1997. Variações espaço-temporais da comunidade zoobêntica. In A planície da inundação o alto Rio Paraná: aspectos físicos, biológicos e socioeconômicos (A.E.A.M. Vazzoler, A.A. Agostinho \& N.S. Hahn, eds.). Ed. da Universidade Estadual de Maringá. 157:177.

UIEDA, V.S. \& GAJARDO, I.C.S.M. 1996. Macroinvertebrados perifíticos encontrados em poções e corredeiras de um riacho. Naturalia 21: 31-47.

VINSON, M.R. \& HAWKINS, C.P. 1998. Biodiversity of stream insects variation at local, basin and regional scales. Annu. Rev. Entomol. 43: 271-293.

Title: Diversity and abundance of the benthic macrofauna in lotic environments from the central region of Rio Grande do Sul State, Brazil.

Authors: Ayres-Peres, L., Sokolowicz, C.C. and Santos, S.

Biota Neotropica, Vol.6 ( number 3): 2006

http://www.biotaneotropica.org.br/v6n3/pt/ abstract?article+bn02106032006

Date Received 03/15/2006 - Revised 09/10/2006

Accepted 10/02/2006

ISSN 1676-0611 